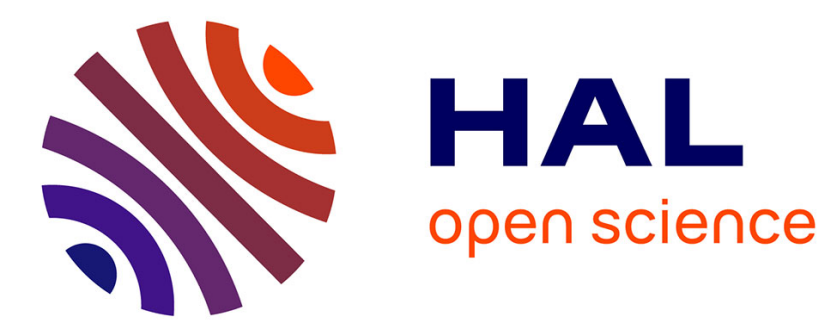

\title{
Intramolecular Michael Additions in Uridine Derivatives: Isolation of the Labile 5'O-C6 Cyclonucleoside
}

\author{
Arnaud Gissot, Stéphane Massip, Philippe Barthélémy
}

\section{To cite this version:}

Arnaud Gissot, Stéphane Massip, Philippe Barthélémy. Intramolecular Michael Additions in Uridine Derivatives: Isolation of the Labile 5'O-C6 Cyclonucleoside. ACS Omega, 2020, 5 (38), pp.2474624753. 10.1021/acsomega.0c03348. hal-02959163

\section{HAL Id: hal-02959163 https://hal.science/hal-02959163}

Submitted on 6 Oct 2020

HAL is a multi-disciplinary open access archive for the deposit and dissemination of scientific research documents, whether they are published or not. The documents may come from teaching and research institutions in France or abroad, or from public or private research centers.
L'archive ouverte pluridisciplinaire HAL, est destinée au dépôt et à la diffusion de documents scientifiques de niveau recherche, publiés ou non, émanant des établissements d'enseignement et de recherche français ou étrangers, des laboratoires publics ou privés. 


\title{
Intramolecular Michael Additions in Uridine Derivatives: Isolation of the Labile 5'O-C6 Cyclonucleoside
}

\author{
Arnaud Gissot,* Stéphane Massip, and Philippe Barthélémy*
}

Cite This: ACS Omega 2020, 5, 24746-24753

Read Online

ABSTRACT: Uridine derivatives undergo a diastereospecific intramolecular hetero Michael addition onto uracil C6 to give cyclo-adducts. In contrast to the potent amine and thiol nucleophiles at the $5^{\prime}$ position of ribose, which readily give the $N$ - and $S$-cyclonucleosides in good yields, the cyclization reaction from the "natural" 5 '-hydroxyl is tedious and has so far been overlooked most probably because of the thermodynamic instability of the $\mathrm{O}$-cycloadduct. Here, we show that the $O$-cyclonucleoside $\mathbf{1}$ can be isolated, although in low isolated yields, in acidic conditions following an original mechanism. Whether such cyclization reactions occur from biologically relevant pyrimidine-based nucleosides is an open question of interest. Given the structures of thymidine-based antiviral drugs, our results suggest a new hypothetical mode of action for these drugs.

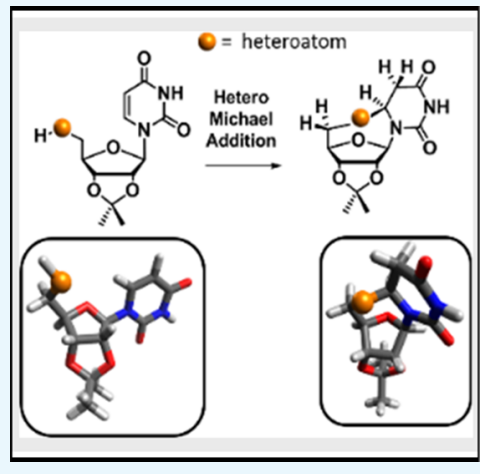

\section{INTRODUCTION}

Cyclonucleosides are defined as nucleoside derivatives wherein an extra bond from a ribose carbon or heteroatom to a purine or pyrimidine carbon is present resulting in a noticeably constrained overall structure. They constitute an important class of synthetic or natural derivatives of nucleosides. ${ }^{1} 2,2^{\prime}$ Anhydro uridines are for instance key intermediates in the synthesis of $2^{\prime}$-modified nucleosides ${ }^{2,3}$ that are crucial in antisense and other pharmacologically active synthetic nucleic acids. Naturally occurring cyclonucleosides are less abundant and have been isolated from marine sponges ${ }^{4,5}$ or result from free radical damages to DNA. ${ }^{6}$ The repertoire of antiviral drugs includes many nucleoside-derived molecules ${ }^{7}$ with cyclonucleosides among them. ${ }^{8,9}$ They have been also associated with anti-proliferative activities. ${ }^{10} 2,2$ '-O-Cyclocytidine was for instance associated with strong antitumor activity and importantly resistance to cytidine deaminase, the enzyme responsible for ara-C inactivation. ${ }^{11}$ Our interest in cyclonucleosides stems from our interest in bio-inspired nucleic acid-based amphiphiles. ${ }^{12-14}$ In the course of our investigations, we regularly came across reluctant couplings with $5^{\prime}$ amino (or 5'-thio)-5'-deoxyuridine. Instead of the desired adducts, formation of cyclonucleosides $\mathbf{2} \mathbf{b}$ and $\mathbf{3 b}$ were observed in these particular cases (Figure 1).

Heteroconjugate addition of 5 -nucleophiles (amine and thiol) onto the uracil ring of uridine derivatives to form compounds $\mathbf{2 a}$ and 3a, respectively, have already been reported in the 1960-1970s. ${ }^{15-17}$ In contrast, due to the poor nucleophilic character of alcohols, the isolation of the $O$ cyclonucleoside $\mathbf{1}$ has never been reported following the Michael addition of the "natural" 5'-OH onto the unmodified uracil. Accordingly, 5'O-C6 uridine cyclonucleosides are not
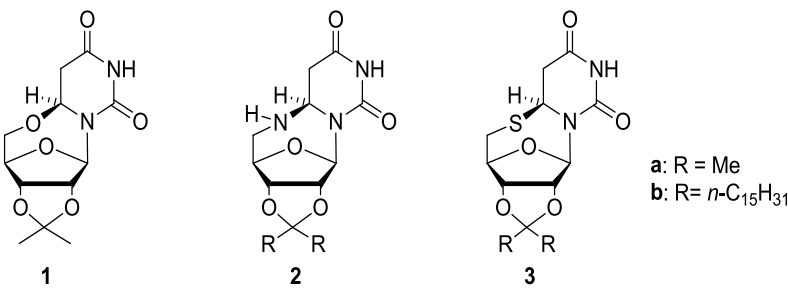

Figure 1. Chemical structures of the cyclonucleosides resulting from Michael addition of $5^{\prime}$-nucleophiles $\left(\mathrm{OH}, \mathrm{NH}_{2}\right.$, and $\left.\mathrm{SH}\right)$ onto the uracil nucleobase.

stable and have been usually reported as simple intermediates, probably because of the facile retro-Michael reaction initiated by the departure of one $\mathrm{C} 4$ uracil proton in basic or acidic conditions. ${ }^{18-20}$ Hence, similar cyclonucleosides have only been isolated from the (1) halogenation of thymidine or uridine (in the absence of hydrogen atoms at the $\mathrm{C} 4$ position or in aprotic neutral conditions $)^{21-24}$ and (2) oxidative coupling of uridine with lead tetra-acetate. ${ }^{25}$ Such conditions are obviously not transposable in vivo. Given the biological relevance of unmodified uridine derivatives in vivo, the direct cyclization of dimethyl ketal uridine $\mathbf{4}$ has been studied in detail. We found that the cyclonucleoside $\mathbf{1}$ can remarkably be

Received: July 13, 2020

Accepted: August 4, 2020

Published: September 15, 2020

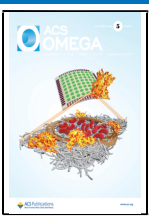


Scheme 1. Synthetic Approach toward the Cyclonucleosides 1, 2a, and $3 a^{a}$

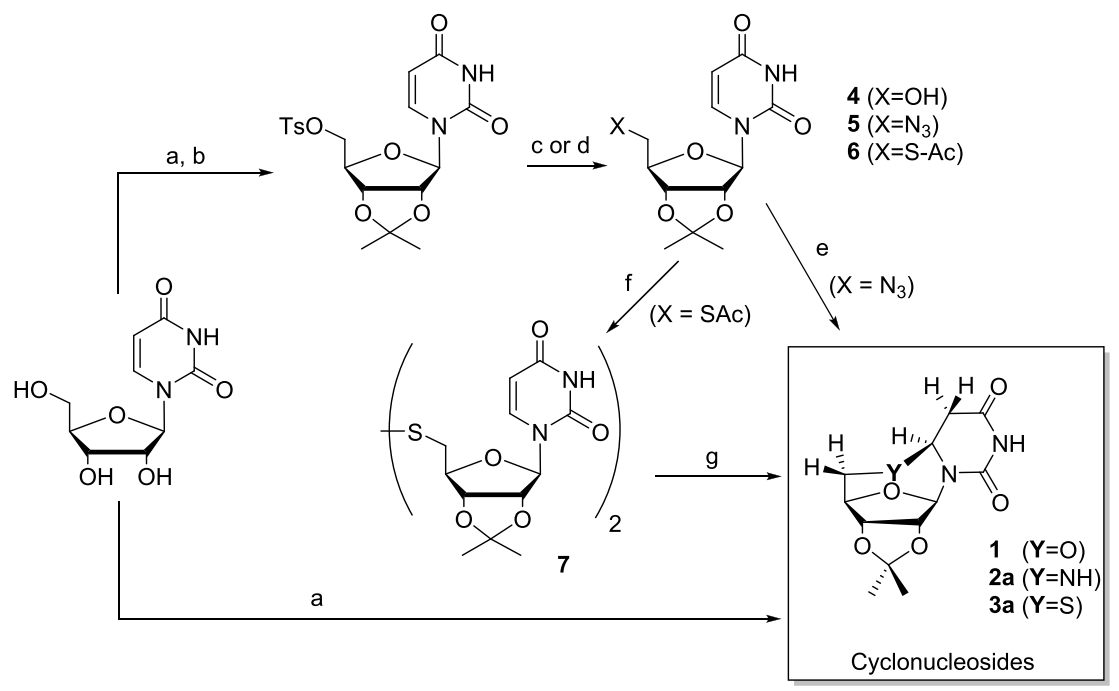

${ }^{a}$ Acetone, cat. $\mathrm{H}_{2} \mathrm{SO}_{4}, \mathrm{MgSO}_{4} 2 \mathrm{~h}, 90 \%$ (4) and $4 \%$ (1); b: TsCl, dry pyridine, $0{ }^{\circ} \mathrm{C}-\mathrm{RT}, 88 \%$; c: $\mathrm{AcSK}, \mathrm{DMF}, 40{ }^{\circ} \mathrm{C}, 95 \%$; $\mathrm{d}: \mathrm{NaN}, \mathrm{DMF}, 40{ }^{\circ} \mathrm{C}$, 90\%; e: $\mathrm{H}_{2}, \mathrm{Pd} / \mathrm{C}, \mathrm{MeOH}, 55 \%$; f: $\mathrm{Na}, \mathrm{MeOH}, 100 \%$; g: $\mathrm{Zn}, \mathrm{TFA}, \mathrm{CH}_{3} \mathrm{CN}, 95 \%$.

isolated in acidic, protic conditions. Our results suggest that the intramolecular addition of 5 '-hydroxyl onto the uracil ring of uridine derivatives is commonplace and has so far been overlooked mainly because of the lability of the cycloadduct. Our results raise open questions relative to the biology of pyrimidine-based nucleosides. More precisely, our results suggest that pyrimidine-based antiviral molecules may well act, at least in part, as their Michael adducts to inhibit viral proliferation.

\section{RESULTS AND DISCUSSION}

Synthesis of Cyclonucleosides. The synthesis of the dimethyl ketal cyclonucleosides $\mathbf{1}, \mathbf{2} \mathbf{a}$, and $\mathbf{3 a}$ is shown in Scheme 1. Briefly, the uridine dimethyl ketal was first tosylated at the $5^{\prime}$-position and then reacted with sodium azide and potassium thioacetate to form the azide and thioacetate precursors 5 and 6, respectively. Instead of the expected thiol or $S$-cyclonucleoside 3a, sodium methoxide deprotection of 6 afforded the disulfide 7 . Acidic conditions were required for the effective reduction of 7 to the corresponding transient thiol that was quantitatively cyclized to the $S$-cyclonucleoside $3 \mathbf{a}$ in situ (step g, Scheme 1). The $N$-cyclonucleoside 2 a was readily obtained following the catalytic hydrogenation of azide 5 . The $\mathrm{O}$-cyclonucleoside $\mathbf{1}$ was obtained as a side-product during the ketal protection of uridine (step a, Scheme 1) in a poor yield (2\%). Sequestration of water molecules in the presence of dry $\mathrm{MgSO}_{4}$ as a desiccant in the reaction medium slightly improved the yield (4\%).

These cyclization reactions involve a favorable 7-exo-trig (according to the Baldwin's rules) intramolecular heteroMichael addition. Unlike amines or thiols, alcohols are poor nucleophiles toward Michael acceptors resulting in equilibrated mixtures of Michael adducts and starting materials. Indeed, $O$ cyclization does take place under basic conditions as evidenced by the gradual deuteration observed at the $\mathrm{C} 5$ of uracil in $\mathrm{D}_{2} \mathrm{O}$ (13\% deuterium exchange after five days in the presence of 4 equivalents of $\mathrm{NaOH}$ at $\mathrm{RT}$, data not shown). Deuteration results from the Michael addition of the $5^{\prime} \mathrm{OH}$ onto the uracil followed by deuteron abstraction from the solvent as previously observed. ${ }^{18,19}$ The resulting $O$-cyclonucleoside $\mathbf{1}$ is unstable in basic media and reverse back to the opened dimethyl ketal uridine $4^{23}$ because of the facile deprotonation at the newly formed methylene C5 (with a 50\% chance to lose the deuteron). Accordingly, a similar cyclonucleoside with no hydrogen atoms at the $\mathrm{C} 5$ is stable in basic conditions. ${ }^{23}$ Formation of the $\mathrm{O}$-cyclonucleoside $\mathbf{1}$ always come along with deuteration when the reaction is conducted in deuterated solvent like acetone $\mathrm{D}_{6}$. Deuteration at C5 is therefore a measure and reminiscent of previous cyclization events. The cyclization reaction is indeed reversible in basic conditions for all the three cyclonucleosides studied (results not shown) in agreement with the reported literature for $\mathrm{N}$-cyclonucleoside $2 \mathbf{a}^{17}$ and $S$-cyclonucleoside $3 \mathbf{a}^{15,16}$ For instance, the $O$ cyclonucleoside 1 was converted back to 4 in a few minutes at $\mathrm{pH} 13$ (TLC monitoring). With the noticeable exception of the $\mathrm{N}$-cyclonucleoside $\mathbf{2 a}$ (that possesses a basic character prone to promote the retro-Michael reaction), the other cyclonucleosides are quite stable in acidic conditions, although the hydrolysis of the ketal is observed at $\mathrm{pH}<2$. Consequently, the $\mathrm{O}$-cyclonucleoside $\mathbf{1}$ was isolated only under acidic conditions (Scheme 1, step a).

The Formation of $\mathrm{O}$-Cyclonucleoside 1 Requires Uracil Protonation and Ketal Exchange. Protonation of uracil is a clear pre-requisite for the cyclization of dimethyl ketal uridine 4 to form the $O$-cyclonucleoside $\mathbf{1}$ in acidic conditions. This was evidenced by monitoring the NMR course of the reaction of 4 with sulfuric acid in acetone $D_{6}$. The uracil nucleobase gets first protonated right upon addition of sulfuric acid as observed in the deshielding of the aromatic protons (Figure S40). In addition, the chemical shifts of the uracil protons and the reaction rates increase with the sulfuric acid content reflecting the unfavorable equilibrium for uracil protonation. Provided that enough sulfuric acid is present, the cyclonucleoside $\mathbf{1}$ is formed rapidly $(<1 \mathrm{~h})$ and its proportion does not change overtime thereafter ruling out the possibility of a slow reaction rate. ${ }^{26}$ In addition, no deuteration at $\mathrm{C} 5$ is detected after 1.5 days when the reaction is conducted in diluted sulfuric acid aqueous solutions with a slow ketal hydrolysis only observed under these conditions (results not shown). Water probably acts as a better base compared to 
Scheme 2. Anchimeric Assistance from a Transient Ketal during the Cyclization of Dimethyl Ketal Uridine 4 (Inset: Molecular Modeling of Intermediate 8)

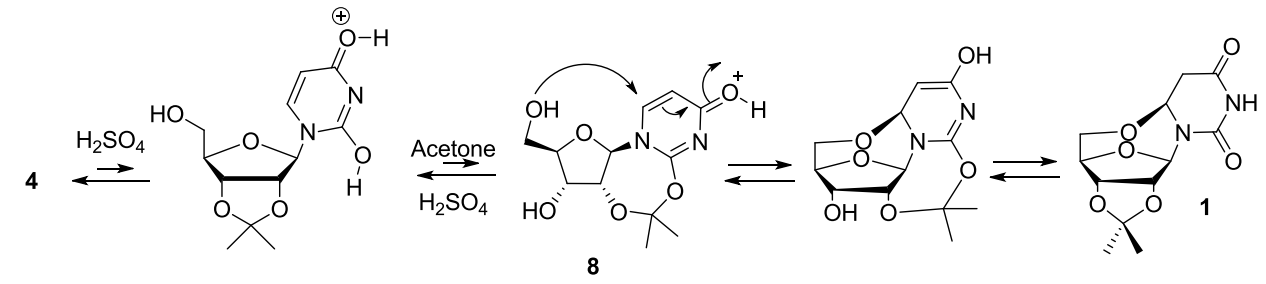

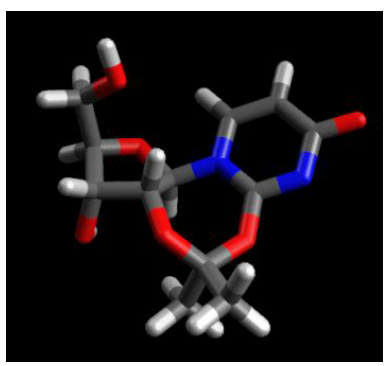

Scheme 3. Anchimeric Assistance from a Transient, Reactive, Cyclonucleoside-Prone 2',2-Ketal (Bottom) during the Cyclization of Uridine Derivatives 4 and $10^{a}$

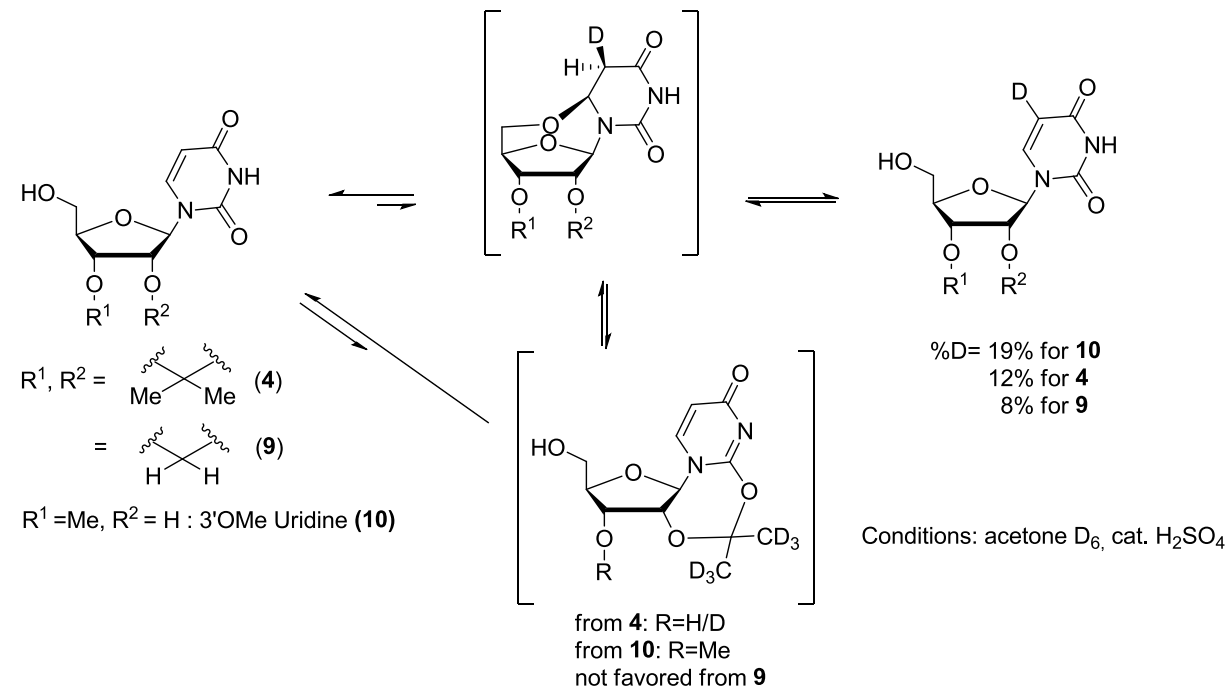

${ }^{a}$ Deuteration was calculated from NMR data after $2 \mathrm{~h}$ of reaction, and the amount of sulfuric acid was purposely low to slow the kinetics of the reaction and prevent ketal exchange from methylene ketal uridine 9 . The absence of $2^{\prime}, 2$-ketal in that case ultimately leads to a slower deuteration rate.

uracil. Protonation obviously activates the uracil ring toward Michael addition. However, another key parameter, ketal exchange, is also crucial to observing the $O$-cyclonucleoside $\mathbf{1}$. For instance, we invariably failed to obtain $\mathbf{1}$ in the absence of acetone as a solvent despite many different tries (among which are Lewis/Brønsted acid catalysis in water or anhydrous DMSO, different temperatures, the presence of cyclodextrins, etc.). Cyclodextrins were purposely used to favor cyclization following the formation of an inclusion between the uridine acetonide 4 and $\beta$-cyclodextrin. The inclusion complex was hypothesized to provide a confined environment favorable to the cyclization reaction. Despite the clear observation of the complex by NMR (Figures S43 and S44), no trace of cyclization and/or deuteration at C5 are observed. In summary, cyclization in acidic conditions seems to take place only in conditions that favor ketal exchange. We therefore propose the mechanism depicted in Scheme 2 for the formation of the cyclonucleoside 1 . The key step consists of the anchimeric assistance of the $\mathrm{O}-2^{\prime}, 3^{\prime}$-ketal of 4 that transiently migrates to the $\mathrm{O}-2^{\prime}, 2$ position in the oxocarbenium ketal 8 that undergoes Michael addition in a subsequent step in the way to 1 .

The importance of the ketal exchange was supported experimentally. The cyclization reaction was investigated starting from three different uridine derivatives: the acetonide 4, the methylene acetal 9, and the 3'OMe uridine 10 (Scheme 3 ). These uridine derivatives are good candidates to assess the importance of ketal migration during the cyclization reaction. As inferred in previous reports, ${ }^{14,15,17}$ if cyclization only relies on the presence of the ketal in the original $2^{\prime}, 3^{\prime}$ position (as in 4), no deuteration at $\mathrm{C} 5$ should be observed with the $3^{\prime} \mathrm{OMe}$ uridine. The methylene acetal 9 should also exhibit the highest rate of deuteration as a result of the higher acetal stability toward acidic conditions compared to the acetonide 4 . Hence, 
the trend in the rate of deuteration $9>4 \gg 10$ should be observed. In contrast, the deuterium exchange (and possibly the cyclonucleoside) should be observed with the $3^{\prime} \mathrm{OMe}$ uridine $\mathbf{1 0}$ if the alleged ketal in the $2^{\prime}, 2$ position is involved (the only ketal position that is accessible from 10). As the methylene acetal uridine 9 is less prone to acetal exchange compared to ketals, the order $\mathbf{1 0}>\mathbf{4}>\mathbf{9}$ should be observed for the deuteration rate. Experimental results clearly support this second hypothesis and our proposed mechanism (Scheme 3 and Figures S41 and S42).

Of note, the $\mathrm{O}$-cyclonucleoside from the $3^{\prime} \mathrm{OMe}$ uridine is neither detected nor isolated despite the higher observed deuteration rate at C5. This observation suggests that the thermodynamically favored ketal in the $\mathrm{O}-2^{\prime}, 3^{\prime}$ position somehow stabilizes the $\mathrm{O}$-cyclonucleoside $\mathbf{1}$ probably as a result of the rigidified ribose ring system. Finally and quite surprisingly, the pure isolated cyclonucleoside 1 reversed rapidly back to dimethyl ketal uridine $\mathbf{4}$ in acidic acetone, i.e., under the conditions employed for its formation. This observation suggests that the cyclonucleoside $\mathbf{1}$ is in equilibrium with the opened dimethyl ketal uridine 4 . The water content in the reaction medium does influence the position of the equilibrium. Indeed, the proportion of the cyclonucleoside increases in the presence of a desiccant and $\mathbf{1}$ is quickly opened back to 4 when water is added to the reaction. Water may serve as a general base catalyst to promote the ring opening of 1 . Of note, if the isolation of cyclonucleoside $\mathbf{1}$ is undoubtedly complex because of its sensitivity to basic and acidic conditions, it is remarkably stable once purified. It has been stored at room temperature under an inert atmosphere for several months with very little conversion to 4 .

Conformation and Stereochemistry Analyses of Cyclonucleosides. A new chiral center at uracil $\mathrm{C}_{6}$ is created upon cyclization. Thus, two diastereomers are expected for the cyclonucleosides and observed previously for halogenated thymidine and uridine. ${ }^{22,23}$ However, a single diastereomer was obtained in our case. For instance, NOESY experiments with the $\mathrm{N}$-cyclonucleoside 2a (and the same goes for the other cyclonucleosides) indicated a clear nuclear Overhauser effect between the $\mathrm{H}_{6}$ and $\mathrm{H}_{5^{\prime}}$ besulting from the addition of the $5^{\prime}$ $\mathrm{NH}_{2}$ onto the si face of the uracil ring at $\mathrm{C}_{6}$ leading to an $R$ absolute configuration at $\mathrm{C}_{6}$ for $\mathbf{2 a}$ (Figure $2 \mathrm{~A}$ ) and $S$ for $\mathbf{1}$ and 3a. This configuration was confirmed both by NMR (the $\mathrm{H}_{1^{\prime}}-$ $\mathrm{C}_{1^{\prime}}$ and the carbonyl $\mathrm{C}_{2}$ bonds of uracil are almost coplanar resulting in a highly deshielded $\mathrm{H}_{1}$, in $\mathbf{1}$ (Figure S35)) and $\mathrm{X}$ ray diffraction studies of the 3 cyclonucleosides (Figure $2 \mathrm{C}$ and Tables S1-S3).

The stereospecificity of the addition is supported by (1) simple molecular modeling, which suggests unfavorable dipolar interactions between the oxygen in the ribose ring and the $\mathrm{C}_{2}$ carbonyl of the uracil upon addition from the re face and (2) $\mathrm{X}$-ray data of the parent $2^{\prime}, 3^{\prime}$-O-isopropylidene-5-bromouridine that clearly shows the $5^{\prime} \mathrm{OH}$ group lying above the si face of the uracil in an anti-conformation in the ground state. ${ }^{27}$ Of note, an opposite stereospecificity was obtained in similar cyclization reactions from the $5^{\prime}-\mathrm{CH}_{2}$ radical. ${ }^{28,29}$ The stereospecificity was in that case ascribed to the formation of a favorable chair configuration in the newly formed sixmembered ring cyclonucleoside, whereas a seven-membered ring is obtained in our case. Although very rigid, the cyclonucleoside-fused tetracyclic system can further theoretically adopt two alternative energy minimum conformations
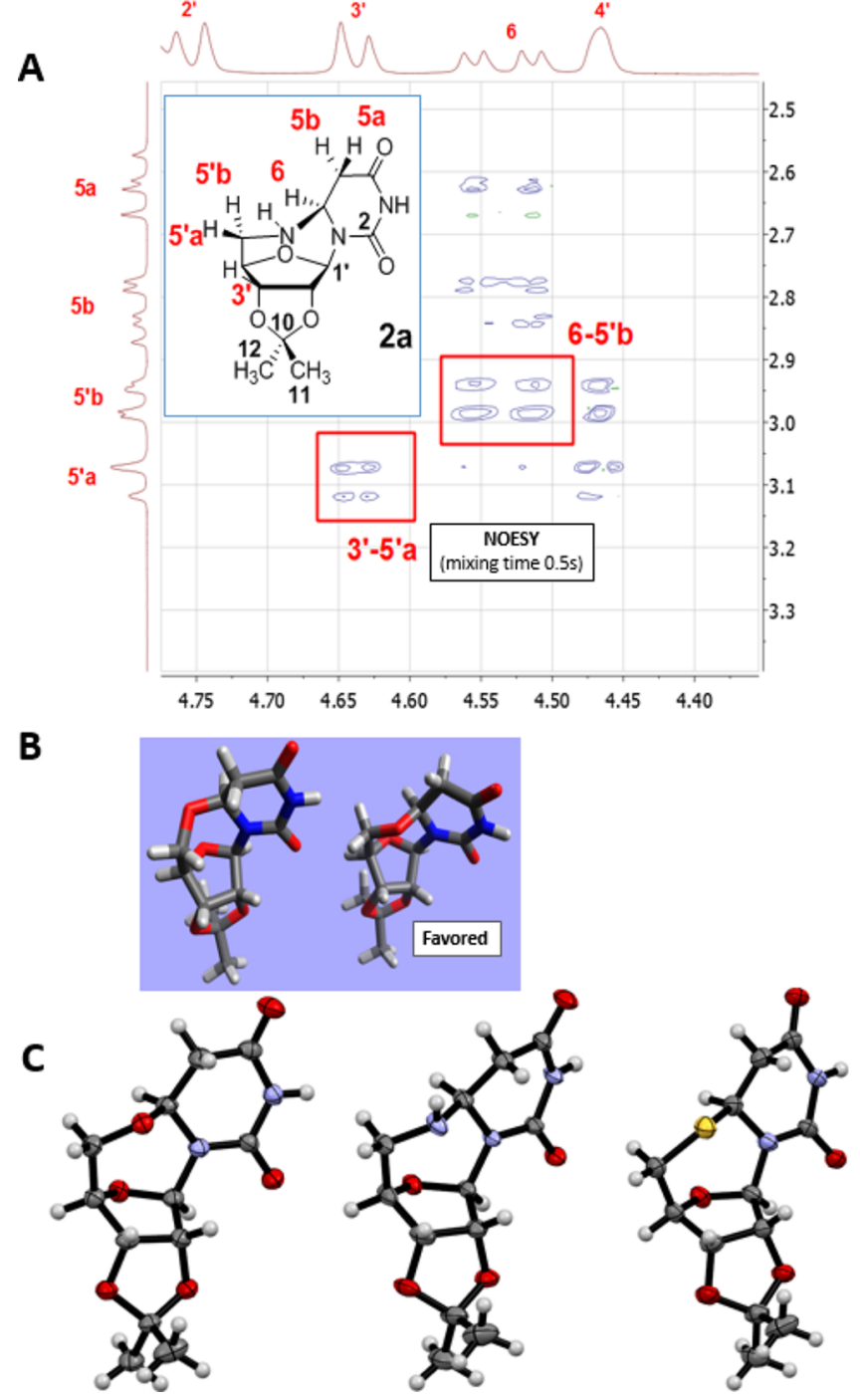

Figure 2. (A) NOESY spectrum of $N$-cyclonucleoside 2a. (B) Energy minimized structures (amber force field) of the two conformers of $O$ cyclonucleoside 1. (C) ORTEP representation of the crystal structure of cyclonucleosides $\mathbf{1}, \mathbf{2 a}$, and $\mathbf{3 a}$ (from left to right).

shown in Figure 2B. They result from two alternative puckers of the seven-membered ring centered at the $5^{\prime}$ heteroatom of the cyclonucleoside. Molecular modeling (Figures S36-S38), NMR, and X-ray results all confirmed the more thermodynamically favored conformation with the $5^{\prime}$ heteroatom pointing upward (right conformer, Figure 2B). In fact, a $\mathrm{H}_{1^{\prime}}-\mathrm{H}_{6}$ and no $\mathrm{H}_{6}-\mathrm{H}_{5^{\prime} \mathrm{b}}$ cross peaks were expected in the NOE experiment for the second conformer (Figure 2A,B on the left for the alternative conformer). Based on the same considerations, a rapid equilibrium between the two conformers appears unlikely and a high energetic barrier is probable for the two conformers to interconvert as no change in the NMR spectrum is observed in the $20-55{ }^{\circ} \mathrm{C}$ range.

Discussion. The formation of the cyclonucleosides 1-3 from their tricyclic precursors involves a favorable 7-exo-trig intramolecular hetero-Michael addition of 5 '-nucleophiles onto the uracil $\alpha, \beta$-unsaturated system at the uracil C6. While the cyclonucleosides 2 and 3 formed from good nucleophiles at the $5^{\prime}$ position most probably result from a regular Michael addition under neutral or slightly acidic conditions (Scheme $1)$, the $5^{\prime}-\mathrm{OH}$ of 4 requires basic conditions to observe the 
deuterium exchange at the uracil $\mathrm{C5}$, the latter being an indirect measure of previous cyclization events. If basic conditions undoubtedly enhance the nucleophilicity of the hydroxyl, they above all favor the retro-Michael process explaining the partial deuteration observed at the C5 (vide supra). Our results showed that the labile cyclonucleoside $\mathbf{1}$ could in contrast be isolated in acidic conditions. Moreover, this reaction is not merely limited to the dimethyl ketal uridine 4. The ketal-free 3'OMe uridine was for instance deuterated at the C5 more rapidly than 4 (Scheme 3). However, the ketal at the original $2^{\prime}-3^{\prime}$ position of the uridine ribose is necessary to allow the isolation of the $O$-cycloadduct. This ketal (or the transiently formed ketal at the 2',2-position; Scheme 2) somehow provided enough stabilizing free energy to the otherwise labile $\mathrm{O}$-cyclonucleoside. Cyclonucleosides are then formed from two different mechanisms depending on the nature of the 5 '-nucleophiles.

Cyclization from Good 5'-Nucleophiles $\left(-\mathrm{NH}_{2}\right.$ and $\left.-\mathrm{SH}\right)$. As observed by others, the isopropylidene protecting the vicinal diols at the $2^{\prime}$ and $3^{\prime}$ positions of the ribose is required to observe cyclization from good $5^{\prime}$-nucleophiles. Some reports hypothesized that "the isopropylidene ring forces the furanose ring into a conformation that favors the proximity of the 5'substituent group to the uracil double bond". ${ }^{17,20,30}$ Simple molecular mechanics (amber force field) and coupling constants measurements favor an alternative explanation based on the conformation of the ribose ring in agreement with Otter et al. ${ }^{20}$ Hence, the minimal distance between the $5^{\prime}$ substituent group and the uracil C6 is obtained for the ketalfree uridine in the $\mathrm{C}^{\prime}$ ' endo conformation (Figure S39). Instead, the ketal may considerably reduce the energy landscape for the ribose ring system toward cyclonucleosideprone conformers. Cyclonucleosides are conformationally constrained with dihedral angles between (1) $\mathrm{H}_{1^{\prime}}$ and $\mathrm{H}_{2^{\prime}}$ and (2) $\mathrm{H}_{3^{\prime}}$ and $\mathrm{H}_{4^{\prime}}$ close to $90^{\circ}$ according to the Karplus equation as evidenced by the absence of observed couplings between these protons in NMR and confirmed by the crystal structure (Figure 2C). The $5 \mathrm{~Hz}$ value obtained for uridine is closer to an acyclic system and reflects the many different conformers that exist in solution for this nucleoside and the low ${ }^{3} J$ values of $3 \mathrm{~Hz}$ in 4 supports the hypothesis that, on average, their conformers are more prone to cyclization compared to uridine. The absence of apparent couplings between $\mathrm{H}_{1^{\prime}}-\mathrm{H}_{2^{\prime}}$ and $\mathrm{H}_{3^{\prime}}-\mathrm{H}_{4^{\prime}}$ is quite unusual in ribose ring systems and speaks for a high-energy transition state with a peculiar and unfavorable sugar-ring pucker. This hypothesis is also in line with the observation that, irrespective of the nucleophilicity of the different 5 -nucleophiles, heat is required for the cyclization reactions to $2 \mathrm{a}$ and $3 \mathbf{a}$. Hence, our results suggest that the critical parameter to reach the transition state is the accessibility of the Michael acceptor toward the 5'nucleophile, i.e., the conformation of the ribose ring more than the nature of the nucleophile. Overall, the ketal protection in $\mathbf{4}$ may provide an entropic gain relative to the unprotected uridine to reach the transition state. In other words, the ketal may simply channel the free energy toward transition state-like conformers in a kinetically controlled manner.

Formation of Cyclonucleoside 1 in Acidic Conditions. Despite its high sensitivity in basic and acidic conditions, the $\mathrm{O}$-cyclonucleoside $\mathbf{1}$ has been successfully formed and isolated, although in a low $4 \%$ yield. We have seen that this low yield is due to an unfavorable equilibrium constant rather than a slow rate of the cyclization reaction. The formation of 1 was found to depend on both the formation of the uracil oxocarbenium and a transient ketal exchange (Scheme 2). Previous reports support our proposed mechanism. Uracil ${ }^{31}$ and uridine ${ }^{32}$ are known to exist mainly as 2,4-dihydroxy and O4-protonated species under acidic conditions in the gas phase and in solution. The 2,4-dihydroxy protonated form was found to predominate in solution as a result of a stabilizing hydrogenbonding network between $\mathrm{O} 2(\mathrm{H}), \mathrm{O}^{\prime}(\mathrm{H})$, and $\mathrm{O}^{\prime}$. This conformation places the $5^{\prime} \mathrm{OH}$ and the uracil ring as well as the uracil $\mathrm{O} 2$ and the ribose $\mathrm{O}_{2}^{\prime}$ in ideal positions to promote both the cyclization and the formation of the O-2',2 ketal. ${ }^{32}$ When transiently formed, the latter ketal is further poised to aid in the cyclization step. Incidentally, the N3 lone pair of $\mathbf{4}$ is no longer conjugated with the carbonyl $\mathrm{C} 4$ after the ketal migration in $\mathbf{8}$ has taken place. Hence, the latter possesses a true $\alpha, \beta$-unsaturated ketone character more prone to undergo Michael addition in comparison to 4. In fact, a similar 7-exotrig cyclization has been reported from an adenosine derivative ${ }^{33}$ with the cyclonucleoside obtained in an excellent $60 \%$ yield. We interpret this difference in the position of the equilibrium between the opened and cyclized forms by the energetic penalty associated with the loss of aromaticity in the pyrimidine cyclonucleoside $\mathbf{1}$ whereas the adenosine cyclonucleoside is still aromatic following the same cyclization.

It is important to notice that the ketal at the $\mathrm{O}-2^{\prime}, 3^{\prime}$ position is not necessarily required for the $\mathrm{O}$-cyclization to take place according to our proposed mechanism. For instance, the highest rate of cyclization was obtained with the $3^{\prime} \mathrm{OMe}$ uridine among all the different uridine derivatives tested (Scheme 3). Our results emphasize that the formation of Ocyclonucleosides from the "natural" 5 '-hydroxyl is not limited to ketal-protected uridine derivatives. Nevertheless, the presence of the ketal protecting group seems somehow necessary to stabilize the fragile polycyclic structure of the $\mathrm{O}$-cyclonucleosides. For instance, the cyclonucleoside from 3'OMe uridine could not be isolated or even detected by NMR. Given its poor stability in basic or wet acidic conditions, the isolation of $\mathbf{1}$ in acidic conditions is remarkable. For instance, the $O$-cyclonucleoside 1 rapidly reverses back to 4 in the conditions used for its formation (acetone + catalytic sulfuric acid)! Why is then $\mathbf{1}$ observed under the exact same conditions following uridine ketalization? Our results demonstrated that the formation of the $\mathrm{O}$-cyclonucleoside is a fully reversible reaction with the starting opened dimethyl ketal uridine 4 being clearly the thermodynamically favored form. In fact and in contrast to thiol and amine nucleophiles, Michael additions from alcohol are usually reversible. In the case of the $\mathrm{O}$-cyclonucleoside $\mathbf{1}$, the loss of aromaticity in the uracil ring and the ring strain associated with its highly constrained structure further disfavor the Michael adduct. We hypothesize that the observation (and isolation) of the $O$-cyclonucleoside 1 is facilitated by the transient formation of the 2',2-ketal intermediate that freezes the glycosidic bond in a favorable anti-conformation that most likely stabilizes the $\mathrm{O}$-cyclonucleoside. Given that both the original $2^{\prime}, 3^{\prime}$ - and the putative reactive $2^{\prime}, 2$-ketal are without any doubt in rapid equilibrium, the presence of the $2^{\prime}, 3^{\prime}$-ketal in the vicinity of the uracil $\mathrm{O} 2$ necessarily increases the chance to form the more reactive $2^{\prime}, 2$ ketal that ultimately stabilizes the $O$-cyclonucleoside structure. According to our hypothesis, the modest yields of 1 obtained could be directly correlated to the proportion of reactive $2^{\prime}-2$ ketal present in solution at equilibrium. In the absence of the original ketal in the $2^{\prime}, 3^{\prime}$-position, the proportion of the 
reactive $2^{\prime}, 2$-ketal over the starting material may be too low to allow for the stabilization of the $\mathrm{O}$-cyclonucleoside even though cyclization events do take place as evidenced by deuterium exchange experiments with $3^{\prime} \mathrm{OMe}$ uridine for instance (Scheme 3). In addition, we have seen that the water content must remain low throughout the reaction to observe and isolate 1 . Water will likely promote the hydrolysis of the fragile and reactive 2 '2-ketal in acidic conditions resulting in $\mathbf{1}$ being formed in lower yields in the absence of molecular sieves (Scheme 1 and text). Water may also act as a proton acceptor to facilitate the retro Michael conversion of the $\mathrm{O}$-cyclonucleoside 1 into 4 . We also considered the possibility for the uracil to be trapped as its enol tautomeric form following the cyclization of intermediate $\mathbf{8}$ (Scheme 2) in the absence of water. Given the absence of a basic character of $\mathrm{H} 5$ in the enol form, no retro Michael reaction is expected from this intermediate. However, the methylene $\mathrm{H} 5$ protons of $\mathbf{1}$ are clearly visible by NMR throughout the reaction course ruling out this hypothesis.

\section{CONCLUSIONS}

In conclusion, ketal-protected uridines with different 5 nucleophiles (amine, thiol, and even the poorly nucleophilic unmodified alcohol) form cyclonucleosides following an intramolecular hetero Michael addition. Our results show that the cyclization of the "natural" 5'-hydroxyl is commonplace in uridine derivatives and has been overlooked so far because of the thermodynamic instability of the $\mathrm{O}$-cyclonucleoside 1. Accordingly, trans-ketalization conditions are required to isolate this elusive intermediate. We believe that the possibility of such intramolecular Michael addition events should always be borne in mind when natural or synthetic pyrimidine-based nucleosides come into play in vivo. In this regard, it is interesting to note that a whole class of thymidinederived antiviral drugs (idoxuridine, trifluridine, and brivudine) possesses a C5 substituent at the thymine that favors Michael addition. The possibility of these antiviral drugs acting as their Michael adducts in the active site of their targeted receptors is an open question raised by our results especially since the antiviral mechanism of action of these drugs is not completely defined. ${ }^{34}$ Uridine/thymidine kinase activity may well be inhibited because of the 5 '-hydroxyl being trapped as an unreactive Michael adduct in the active site. Following this hypothesis, the active site of the targeted enzyme should be more complementary to the cyclized form of the nucleoside drug providing the energy necessary to drive the unfavorable equilibrium toward the cyclonucleoside. In line with these considerations, a stable anhydrocyclonucleoside was found to inhibit uridine kinase. ${ }^{35}$ We hope further developments and investigations into the mechanism of action of pyrimidinebased antiviral drugs will benefit from our results. Attempts aiming at characterizing such pyrimidine cycloadducts in biological media will yet remain challenging due to their poor stability.

\section{EXPERIMENTAL SECTION}

General Information. All reagent-grade chemicals were obtained from commercial suppliers and used as received unless otherwise stated. All reactions were carried out under an argon atmosphere. Yields refer to chromatographically and spectroscopically $\left({ }^{1} \mathrm{H}\right.$ NMR) homogeneous materials. ${ }^{1} \mathrm{H}$ NMR and ${ }^{13} \mathrm{C}$ NMR spectra were recorded on a Bruker
Avance $300\left({ }^{1} \mathrm{H}: 300 \mathrm{MHz},{ }^{13} \mathrm{C}: 75.46 \mathrm{MHz}\right)$ spectrometer using residual $\mathrm{CHCl}_{3}$ as the internal reference $(7.26 \mathrm{ppm})$ and at $293 \mathrm{~K}$. The chemical shifts $(\delta)$ and coupling constants $(J)$ are expressed in parts per million and Hertz, respectively. FTIR spectra were recorded on a PerkinElmer FT spectrometer Spectrum 2 (UATR 2). HRMS spectra were recorded with a Waters Q-TOF 2 spectrometer in the electrospray ionization (ESI) mode, Bruker Maxis 4G mass spectrometer, or Thermo Fisher Q-Exactive mass spectrometer. Analytical thin-layer chromatography was performed using silica gel 60 F254 precoated plates (Merck) with visualization by ultraviolet light, potassium permanganate, or sulfuric acid. Flash chromatography was performed on silica gel $(0.043-0.063 \mathrm{~mm})$.

Synthesis of Cyclonucleoside Precursors. The azide and thioacetate precursors 5 and $\mathbf{6}$ were prepared following standard protocols starting from uridine.

Disulfide 7. 5' -thioacetate-5'-deoxy dimethyl ketal uridine (194 $\mathrm{mg}, 0.567 \mathrm{mmol}$ ) was dissolved in freshly prepared and degassed (freezed in liquid nitrogen and degassed then filled with argon four times) $1 \mathrm{M} \mathrm{MeONa}$ solution (1.2 mL, 12 $\mathrm{mmol})$. The reaction was stirred at RT for $12 \mathrm{~h}$, and the solvent evaporated under reduced pressure. Flash chromatography (petroleum ether/AcOEt 90/10) afforded the disulfide 7 (170 mg, 100\% yield). $R_{\mathrm{f}}=0.25$ (petroleum ether/AcOEt 88/ 12); ${ }^{1} \mathrm{H}$ NMR (300 MHz, $\left.\mathrm{CDCl}_{3}\right) \delta 10.09$ (s, 1H, NH), 7.28 $(\mathrm{d}, J=8.0,1 \mathrm{H}, 6), 5.74(\mathrm{~d}, J=8.0,1 \mathrm{H}, 5), 5.54(\mathrm{~d}, J=1.4 \mathrm{~Hz}$, $\left.1 \mathrm{H}, \mathbf{1}^{\prime}\right), 5.06\left(\mathrm{dd}, J=6.5,1.4 \mathrm{~Hz}, 1 \mathrm{H}, 2^{\prime}\right), 4.82(\mathrm{dd}, J=6.5,4.0$ $\left.\mathrm{Hz}, 1 \mathrm{H}, 3^{\prime}\right), 4.32-4.38\left(\mathrm{~m}, 1 \mathrm{H}, 4^{\prime}\right), 3.01-3.14\left(\mathrm{~m}, 2 \mathrm{H}, \mathbf{5}^{\prime}\right)$, 1.54 (s, 3H, Me), 1.33 (s, 3H, Me). ${ }^{13} \mathrm{C} \mathrm{NMR} \mathrm{(75} \mathrm{MHz,}$ $\left.\mathrm{CDCl}_{3}\right) \delta 25.33(\mathrm{Me}), 27.17(\mathrm{Me}), 41.65\left(5^{\prime}\right), 83.48\left(3^{\prime}\right)$, $84.58\left(\mathbf{2}^{\prime}\right), 86.59\left(4^{\prime}\right), 95.88\left(\mathbf{1}^{\prime}\right), 102.73(5), 114.57$ (ketal), 143.42 (6), 150.21 (2), 164.04 (4); IR (ATR) $\nu_{\max }\left(\mathrm{cm}^{-1}\right)$ 3060, 2989, 2936, 1682, 1455, 1378, 1267, 1209, 1064, 727, 566.

Synthesis of Cyclonucleosides (See Figure 2 for Numbering). O-Cyclonucleoside 1. Uridine (5.18 g, 21.21 $\mathrm{mmol}$ ) was dispersed in $250 \mathrm{~mL}$ of acetone (not dry). Concentrated sulfuric acid $(2.5 \mathrm{~mL}, 45.5 \mathrm{mmol})$ was then added dropwise under stirring at room temperature. The dispersion turned to a clear solution after $30 \mathrm{~min}$, and the reaction was stopped after $2 \mathrm{~h}$ by the dropwise addition of 8 $\mathrm{mL}$ of triethylamine at $0{ }^{\circ} \mathrm{C}(\mathrm{NB}$ : the less basic pyridine should be used instead if the $\mathrm{O}$-cyclonucleoside $\mathbf{1}$ is the desired molecule). The solvent was evacuated under reduced pressure, and the crude was purified by flash chromatography (DCM/ $\mathrm{MeOH} 94 / 6)$ to afford $5.42 \mathrm{~g}(90 \%)$ of uridine dimethyl ketal as well as $103 \mathrm{mg}$ of $\mathbf{1}(2 \%) . R_{\mathrm{f}}=0.75(\mathrm{DCM} / \mathrm{MeOH} 80 / 20)$; ${ }^{1} \mathrm{H}$ NMR (300 MHz, $\mathrm{CDCl}_{3}$ ) $\delta 8.51$ (br s, $\left.1 \mathrm{H}, \mathrm{NH}\right), 6.19$ (s, $\left.1 \mathrm{H}, \mathbf{1}^{\prime}\right), 5.05(\mathrm{dd}, J=9.0,5.4 \mathrm{~Hz}, 1 \mathrm{H}, 6), 4.70\left(\mathrm{~m}, 2 \mathrm{H}, 5^{\prime}\right)$, 4.49 (d, $J=2.2 \mathrm{~Hz}, 1 \mathrm{H}, 4^{\prime}$ ), $4.02\left(\mathrm{~d}, J=12.8 \mathrm{~Hz}, 1 \mathrm{H}, 2^{\prime}\right), 3.70$ (dd, $J=12.8,2.2 \mathrm{~Hz}, 1 \mathrm{H}, 3^{\prime}$ ), 2.95 (dd, $J=17.1,5.4 \mathrm{~Hz}, 1 \mathrm{H}$, 5a), 2.73 (dd, $J=17.1,9.0 \mathrm{~Hz}, 1 \mathrm{H}, 5 \mathbf{b}), 1.50$ (s, 3H, 12), 1.31 $(\mathrm{s}, 3 \mathrm{H}, 11) ;{ }^{13} \mathrm{C} \mathrm{NMR}\left(75 \mathrm{MHz}, \mathrm{CDCl}_{3}\right) \delta 24.79(\mathbf{1 1}), 26.38$ (12), $38.17(5), 74.53\left(5^{\prime}\right), 82.44\left(3^{\prime}\right), 84.21(6), 86.97\left(4^{\prime}\right)$, $87.61\left(\mathbf{2}^{\prime}\right), 92.14,92.16\left(\mathbf{1}^{\prime}\right), 112.82$ (10), 150.17 (2), 166.89 (4). HRMS $m / z[\mathrm{M}+\mathrm{Na}]^{+}$calculated for $\mathrm{C}_{12} \mathrm{H}_{16} \mathrm{~N}_{2} \mathrm{O}_{6} \mathrm{Na}$ : 307.0900, found 307.0895.

$\mathrm{N}$-Cyclonucleoside 2a. 5'-Azido-5'-deoxy dimethyl ketal uridine $(370 \mathrm{mg}, 1.196 \mathrm{mmol})$ was dissolved in methanol (4 $\mathrm{mL})$, and palladium on charcoal (18 mg, cat.) was added. The flask was evacuated then filled with hydrogen (repeated twice), and the reaction was stirred at $50{ }^{\circ} \mathrm{C}$ for $12 \mathrm{~h}$. The catalyst was filtered off, and the crude was concentrated under vacuum 
before flash chromatography (AcOEt/pentane 80/20) to obtain 2a (209 mg, 55\% yield). $R_{\mathrm{f}}=0.28(\mathrm{AcOEt} /$ pentane 86/14); ${ }^{1} \mathrm{H}$ NMR (300 MHz, $\left.\mathrm{CDCl}_{3}\right) \delta 8.01$ (br s, $1 \mathrm{H}, \mathrm{NH}$ ), 7.93 (br s, $1 \mathrm{H}, \mathrm{NH}), 6.34\left(\mathrm{~s}, 1 \mathrm{H}, \mathbf{1}^{\prime}\right), 4.75(\mathrm{~d}, J=5.9 \mathrm{~Hz}, 1 \mathrm{H}$, $\left.2^{\prime}\right), 4.64\left(\mathrm{~d}, J=5.9 \mathrm{~Hz}, 1 \mathrm{H}, 3^{\prime}\right), 4.54(\mathrm{dd}, J=12.2,3.9 \mathrm{~Hz}, 1 \mathrm{H}$, 6), 4.47 (m, 1H, 4'), 3.11 (d, J=13.7 Hz, 1H, 5'a), 2.97 (d, J = $13.7 \mathrm{~Hz}, 1 \mathrm{H}, \mathbf{5}$ 'b), 2.81 (dd, $J=16.4,3.9 \mathrm{~Hz}, 1 \mathrm{H}, \mathbf{5 b}$ ), 2.62 (dd, $J=16.4,12.2 \mathrm{~Hz}, 1 \mathrm{H}, \mathbf{5 a}), 1.51(\mathrm{~s}, 3 \mathrm{H}, 12), 1.31(\mathrm{~s}, 3 \mathrm{H}$, 11). $\left.{ }^{13} \mathrm{C} \mathrm{NMR} \mathrm{(75} \mathrm{MHz,} \mathrm{CDCl}_{3}\right) \delta 24.83$ (11), 26.49 (12), $38.76(5), 52.40\left(5^{\prime}\right), 68.17(6), 83.87\left(3^{\prime}\right), 86.84\left(4^{\prime}\right), 88.18$ $\left(\mathbf{2}^{\prime}\right)$, 92.03, $92.01\left(\mathbf{1}^{\prime}\right), 112.43$ (10), 150.98 (2), 167.37 (4). HRMS $m / z[\mathrm{M}+\mathrm{Na}]^{+}$calculated for $\mathrm{C}_{12} \mathrm{H}_{17} \mathrm{~N}_{3} \mathrm{O}_{5} \mathrm{Na}$ : 306.1060, found 306.1062.

$\mathrm{N}$-Cyclonucleoside $2 b .{ }^{1} \mathrm{H} \mathrm{NMR}\left(300 \mathrm{MHz}, \mathrm{CDCl}_{3}\right) \delta 7.57$ (br s, $1 \mathrm{H}, \mathrm{NH}), 6.34\left(\mathrm{~s}, 1 \mathrm{H}, \mathbf{1}^{\prime}\right), 4.74\left(\mathrm{~d}, J=5.9 \mathrm{~Hz}, 1 \mathrm{H}, 2^{\prime}\right)$, $4.61\left(\mathrm{~d}, J=5.9 \mathrm{~Hz}, 1 \mathrm{H}, 3^{\prime}\right), 4.54(\mathrm{dd}, J=12.1,4.1 \mathrm{~Hz}, 1 \mathrm{H}, 6)$, 4.47 (m, 1H, 4'), 3.10 (br d, $J=13.7 \mathrm{~Hz}, 1 \mathrm{H}, \mathbf{5}^{\prime} \mathbf{a}$ ), 2.97 (dd, $J$ $\left.=13.7,2.1 \mathrm{~Hz}, 1 \mathrm{H}, \mathbf{5}^{\prime} \mathbf{b}\right), 2.82(\mathrm{dd}, J=16.3,4.0 \mathrm{~Hz}, 1 \mathrm{H}, \mathbf{5 b})$, $2.62(\mathrm{dd}, J=16.4,12.1 \mathrm{~Hz}, 1 \mathrm{H}, 5 \mathrm{a}), 1.67(\mathrm{~m}, 2 \mathrm{H}), 1.53(\mathrm{~m}$, $2 \mathrm{H}), 1.41(\mathrm{~m}, 2 \mathrm{H}), 1.25(\mathrm{~m}, 50 \mathrm{H}), 0.88(\mathrm{t}, J=6.9 \mathrm{~Hz}, 6 \mathrm{H}$, $\mathrm{Me}) .{ }^{13} \mathrm{C} \mathrm{NMR}\left(75 \mathrm{MHz}, \mathrm{CDCl}_{3}\right) \delta 14.15,22.74,23.11$, 24.28, 29.42, 29.65, 29.75, 29.88, 29.96, 31.98, 36.65, 36.81, $38.68(5), 52.40\left(5^{\prime}\right), 68.20(6), 83.96\left(3^{\prime}\right), 87.15\left(4^{\prime}\right), 88.28$ $\left(\mathbf{2}^{\prime}\right), 92.02\left(\mathbf{1}^{\prime}\right), 116.21$ (10), 151.37 (2), 168.15 (4).

S-Cyclonucleoside 3a. Disulfide $7(100 \mathrm{mg}, 0.167 \mathrm{mmol}$ ) was dissolved in acetonitrile $(5 \mathrm{~mL})$. Trifluoroacetic acid $(0.2$ $\mathrm{mL}, 1.18 \mathrm{mmol}$ ) followed by zinc (90 $\mathrm{mg}, 1.38 \mathrm{mmol}$ ) was added, and the reaction was stirred at $40^{\circ} \mathrm{C}$ for $3 \mathrm{~h}$. Water was added $(\mathrm{pH}=5)$, and the crude was extracted with dichloromethane. Flash chromatography (DCM/MeOH 98/ 2) afforded $96 \mathrm{mg}$ of $3 \mathrm{a}(95 \%) . R_{\mathrm{f}}=0.47(\mathrm{DCM} / \mathrm{MeOH} 94 /$ 6); ${ }^{1} \mathrm{H}$ NMR (300 MHz, $\left.\mathrm{CDCl}_{3}\right) \delta 7.83$ (br s, $1 \mathrm{H}, \mathrm{NH}$ ), 6.17 $\left(\mathrm{s}, 1 \mathrm{H}, \mathbf{1}^{\prime}\right), 4.95\left(\mathrm{~d}, J=5.4 \mathrm{~Hz}, 1 \mathrm{H}, 2^{\prime}\right), 4.95(\mathrm{dd}, J=9.0,6.3$ $\mathrm{Hz}, 1 \mathrm{H}, 6), 4.92-4.89\left(\mathrm{~m}, 1 \mathrm{H}, 4^{\prime}\right), 4.64(\mathrm{~d}, J=6.0 \mathrm{~Hz}, 1 \mathrm{H}$, $\left.3^{\prime}\right), 3.16\left(\mathrm{dd}, J=14.7,3.0 \mathrm{~Hz}, 1 \mathrm{H}, \mathbf{5}^{\prime} \mathbf{b}\right), 3.11(\mathrm{dd}, J=17.3,6.3$ $\mathrm{Hz}, 1 \mathrm{H}, 5), 2.81$ (dd, $J=17.3,9.0 \mathrm{~Hz}, 1 \mathrm{H}, 5), 2.70$ (dd, $J=$ 14.7, $\left.1.7 \mathrm{~Hz}, 1 \mathrm{H}, \mathbf{5}^{\prime} \mathrm{a}\right), 1.54(\mathrm{~s}, 3 \mathrm{H}, 12), 1.34(\mathrm{~s}, 3 \mathrm{H}, 1 \mathbf{1}) \cdot{ }^{13} \mathrm{C}$ NMR (75 MHz, $\left.\mathrm{CDCl}_{3}\right) \delta 24.77$ (11), 26.48 (12), $37.00\left(5^{\prime}\right)$, 37.13 (5), $56.12(6), 84.41\left(3^{\prime}\right), 88.05\left(4^{\prime}\right), 88.44\left(2^{\prime}\right), 94.91$ (br, $\mathbf{1}^{\prime}$ ), 112.93 (10), 150.70 (2), 166.55 (4). HRMS $m / z[\mathrm{M}$ $+\mathrm{Na}]^{+}$calculated for $\mathrm{C}_{12} \mathrm{H}_{16} \mathrm{~N}_{2} \mathrm{O}_{5} \mathrm{NaS}$ : 323.0672, found 323.0674 .

S-Cyclonucleoside 3b. ${ }^{1} \mathrm{H}$ NMR (300 $\left.\mathrm{MHz}, \mathrm{CDCl}_{3}\right) \delta 7.51$ (s, $1 \mathrm{H}, \mathrm{NH}), 6.17\left(\mathrm{~s}, 1 \mathrm{H}, \mathbf{1}^{\prime}\right), 4.96(\mathrm{dd}, J=9.0,6.1 \mathrm{~Hz}, 1 \mathrm{H}, 6)$, $4.94\left(\mathrm{~d}, J=6.0 \mathrm{~Hz}, 1 \mathrm{H}, 2^{\prime}\right), 4.91\left(\mathrm{~d}, J=3.4 \mathrm{~Hz}, 1 \mathrm{H}, 4^{\prime}\right), 4.62$ (d, $\left.J=6.0 \mathrm{~Hz}, 1 \mathrm{H}, 3^{\prime}\right), 3.12\left(\mathrm{dd}, J=14.2,3.3 \mathrm{~Hz}, 1 \mathrm{H}, \mathbf{5}^{\prime} \mathbf{b}\right)$, $3.11(\mathrm{dd}, J=17.1,6.1 \mathrm{~Hz}, 1 \mathrm{H}, 5), 2.80(\mathrm{dd}, J=17.2,9.1 \mathrm{~Hz}$, $1 \mathrm{H}, \mathbf{5}), 2.70\left(\mathrm{dd}, J=14.6,1.7 \mathrm{~Hz}, 1 \mathrm{H}, \mathbf{5}^{\prime} \mathrm{a}\right), 1.75-1.66(\mathrm{~m}$, $1 \mathrm{H}), 1.58-1.50(\mathrm{~m}, 2 \mathrm{H}), 1.48-1.36(\mathrm{~m}, 2 \mathrm{H}), 1.33-1.19(\mathrm{~m}$, $52 \mathrm{H}), 0.88\left(\mathrm{dd}, J=32.8,7.0 \mathrm{~Hz}, 6 \mathrm{H}, \mathbf{C H}_{3}\right) ;{ }^{13} \mathrm{C} \operatorname{NMR}(75$ $\left.\mathrm{MHz}, \mathrm{CDCl}_{3}\right) \delta 14.26\left(\mathrm{CH}_{3}\right), 22.82,23.09,24.32,29.50$, 29.72, 29.80, 29.91, 30.01, 32.06, 36.64, $36.99\left(5^{\prime}\right), 37.13(5)$, $56.10(6), 84.62\left(3^{\prime}\right), 88.24\left(4^{\prime}\right), 88.61\left(2^{\prime}\right), 94.93\left(b r, 1^{\prime}\right)$, 116.80 (ketal), 150.78 (2), 166.74 (4).

\section{ASSOCIATED CONTENT}

\section{SI Supporting Information}

The Supporting Information is available free of charge at https://pubs.acs.org/doi/10.1021/acsomega.0c03348.

NMR spectra, X-ray analyses, and mass spectra of the different cyclonucleosides, energy-minimized structures for the different diastereomers/conformers of the different cyclonucleosides, NMR course and deuterium exchange experiments from different uridine derivatives, and the inclusion complex between dimethyl ketal uridine 4 and $\beta$-cyclodextrin (PDF)

Crystallographic data of $\mathrm{C}_{13} \mathrm{H}_{17} \mathrm{Cl}_{3} \mathrm{~N}_{2} \mathrm{O}_{6}$, compound $\mathbf{1}$ (CIF)

Crystallographic data of $\mathrm{C}_{13} \mathrm{H}_{19} \mathrm{Cl}_{2} \mathrm{~N}_{3} \mathrm{O}_{5}$, compound 2a (CIF)

Crystallographic data of $\mathrm{C}_{24} \mathrm{H}_{32} \mathrm{~N}_{4} \mathrm{O}_{10} \mathrm{~S}_{2}$, compound 3a (CIF)

\section{AUTHOR INFORMATION}

\section{Corresponding Authors}

Arnaud Gissot - CNRS, INSERM, ARNA, UMR 5320, U1212, Univ. Bordeaux, F-33000 Bordeaux, France; (1) orcid.org/0000-0002-0942-9087; Phone: +33 557574 634; Email: arnaud.gissot@u-bordeaux.fr

Philippe Barthélémy - CNRS, INSERM, ARNA, UMR 5320, U1212, Univ. Bordeaux, F-33000 Bordeaux, France; - orcid.org/0000-0003-3917-0579; Email: philippe.barthelemy@inserm.fr

\section{Author}

Stéphane Massip - CNRS UMS 3033, INSERM US001, IECB, Univ. Bordeaux, F-33600 Pessac, France; (o orcid.org/ 0000-0001-5270-2061

Complete contact information is available at:

https://pubs.acs.org/10.1021/acsomega.0c03348

\section{Notes}

The authors declare no competing financial interest.

\section{ACKNOWLEDGMENTS}

Florent Briée is acknowledged for preliminary experiments and Dr. Valérie Desvergnes for proofreading of this manuscript. The authors acknowledge financial supports from Inserm Transfert. This work has benefited from the facilities and expertise of the Biophysical and Structural Chemistry plateform (BPCS) at IECB, CNRS UMS3033, Inserm US001, Bordeaux University http://www.iecb.u-bordeaux.fr/index. php/en/technology-platforms.

\section{REFERENCES}

(1) Mieczkowski, A.; Roy, V.; Agrofoglio, L. A. Preparation of Cyclonucleosides. Chem. Rev. 2010, 110, 1828-1856.

(2) Kirschenheuter, G. P.; Zhai, Y.; Pieken, W. A. An Improved Synthesis of 2'-Azido-2'-Deoxyuridine. Tetrahedron Lett. 1994, 35, $8517-8520$.

(3) Dai, Q.; Frederiksen, J. K.; Anderson, V. E.; Harris, M. E.; Piccirilli, J. A. Efficient Synthesis of $\left[2^{\prime}-180\right]$ Uridine and Its Incorporation into Oligonucleotides: A New Tool for Mechanistic Study of Nucleotidyl Transfer Reactions by Isotope Effect Analysis. J. Org. Chem. 2008, 73, 309-311.

(4) Capon, R. J.; Trotter, N. S. N3,5-Cycloxanthosine, the First Natural Occurrence of a Cyclonucleoside. J. Nat. Prod. 2005, 68, 1689-1691.

(5) Menna, M.; Aiello, A.; D’Aniello, F.; Fattorusso, E.; Imperatore, C.; Luciano, P.; Vitalone, R. Further Investigation of the Mediterranean Sponge Axinella Polypoides: Isolation of a New Cyclonucleoside and a New Betaine. Mar. Drugs 2012, 10, 25092518.

(6) Chatgilialoglu, C.; Ferreri, C.; Terzidis, M. A. Purine 5',8Cyclonucleoside Lesions: Chemistry and Biology. Chem. Soc. Rev. 2011, 40, 1368-1382. 
(7) De Clercq, E.; Li, G. Approved Antiviral Drugs over the Past 50 Years. Clin Microbiol Rev 2016, 29, 695-747.

(8) Harnden, M. R.; Mock, G. A. Antiviral Agents, Their Preparation and Use. EP0060099A1, September 15, 1982.

(9) Chun, B.-K.; Hassan, A.; Hollecker, L.; Stuyver, L. J.; Wang, P.; Watanabe, K. A. Compounds with the bicyclo[4.2.1] nonane system for the treatment of flaviviridae infections. WO2004013300A2, February 12, 2004.

(10) Mieczkowski, A.; Agrofoglio, L. A. Potential and Perspectives of Cyclonucleosides. Curr. Med. Chem. 2010, 17, 1527-1549.

(11) Hamamura, E. K.; Prystasz, M.; Verheyden, J. P. H.; Moffatt, J. G.; Yamaguchi, K.; Uchida, N.; Sato, K.; Nomura, A.; Shiratori, O. Reactions of 2-Acyloxyisobutyryl Halides with Nucleosides. 6. Synthesis and Biological Evaluation of Some 3'-Acyl Derivatives of 2,2'-Anhydro-1-(.Beta.-D-Arabinofuranosyl)Cytosine Hydrochloride. J. Med. Chem. 1976, 19, 654-662.

(12) Gissot, A.; Camplo, M.; Grinstaff, M. W.; Barthélémy, P. Nucleoside, Nucleotide and Oligonucleotide Based Amphiphiles: A Successful Marriage of Nucleic Acids with Lipids. Org. Biomol. Chem. 2008, 6, 1324-1333.

(13) Patwa, A.; Gissot, A.; Bestel, I.; Barthélémy, P. Hybrid Lipid Oligonucleotide Conjugates: Synthesis, Self-Assemblies and Biomedical Applications. Chem. Soc. Rev. 2011, 40, 5844-5854.

(14) Patwa, A.; Gissot, A.; Oumzil, K.; Barthélémy, P. Lipid Oligonucleotide Bioconjugates: Applications in Medicinal Chemistry. In DNA in Supramolecular Chemistry and Nanotechnology; Stulz, E.; Clever, G. Wiley: 2015; pp. 276-293.

(15) Bannister, B.; Kagan, F. The Synthesis of Nucleoside and Nucleotide Analogs Derived from Uridine*. J. Am. Chem. Soc. 1960, 82, 3363-3368.

(16) Chambers, R. W.; Kurkov, V. The Structure and Properties of Some Sulfur Analogs of Acetoneuridine. J. Am. Chem. Soc. 1963, 85, $2160-2164$

(17) Isono, K.; Azuma, T. Formation and Characterization of 5'Deoxy-5', 6-Epimino-5, 6-Dihydro-2', 3'-O-Isopropylideneuridine. Chem. Pharm. Bull. 1972, 20, 193-196.

(18) Santi, D. V.; Brewer, C. F. Model Studies of Thymidylate Synthetase. Neighboring-Group Facilitation of Electrophilic Substitution Reactions of Uracil Furanosides. J. Am. Chem. Soc. 1968, 90, 6236-6238.

(19) Cushley, R. J.; Lipsky, S. R.; Fox, J. J. Reactions of 5Fluorouracil Derivatives with Sodium Deuteroxide. Tetrahedron Lett. 1968, 9, 5393-5396.

(20) Otter, B. A.; Falco, E. A.; Fox, J. J. Nucleosides. LVIII. Transformations of Pyrimidine Nucleosides in Alkaline Media. 3. Conversion of 5-Halouridines into Imidazoline and Barbituric Acid Nucleosides. J. Org. Chem. 1969, 34, 1390-1396.

(21) Lipkin, D.; Rabi, J. A. Iodination of Thymidine. Synthesis of 06,5'-Cyclothymidine. J. Am. Chem. Soc. 1971, 93, 3309-3310.

(22) Lipshutz, B. H.; Hayakawa, H.; Kato, K.; Lowe, R. F.; Stevens, K. L. A Novel Route to Pyrimidine Nucleosides via Intramolecular Couplings of Bases with 2'-Deoxyribosides: Quick and Stereospecific...but with a "Twist". Synthesis 1994, 12, 1476-1484.

(23) Mieczkowski, A.; Peltier, P.; Zevaco, T.; Agrofoglio, L. A. Preparation of C5-Substituted O6,5'-Cyclouridine. Tetrahedron 2009, 65, 4053-4059.

(24) Hirota, K.; Tomishi, T.; Sako, M.; Maki, Y. Nucleosides. Part 5. Isolation and characterization of the stable cyclic adducts, $(5 \mathrm{R}, 6 \mathrm{~S})$ and $(5 \mathrm{~S}, 6 \mathrm{~S})$-bromo-O6,5'-cyclo-5,6-dihydrouridines in the bromination of $2^{\prime}, 3^{\prime}$-O-isopropylideneuridine with $\mathrm{N}$-bromosuccinimide. $J$. Chem. Soc., Perkin Trans. 1 1988, 1, 2227-2231.

(25) Kameyama, K.; Sako, M.; Hirota, K.; Maki, Y. Reaction of Nucleosides with Lead Tetra-Acetate: Facile Formation of Cyclonucleosides. J. Chem. Soc., Chem. Commun. 1984, 24, 1658-1659.

(26) A detailed analysis of the thermodynamics of the O-cyclization reaction is further complicated by the use of acetone as the solvent required to cope with the competing acid-catalyzed acetonide hydrolysis. A slow aldol side reaction is also observed from acetone and attempts to cyclize dimethyl ketal uridine 4 in hot DMSO or toluene proved unsuccessful.

(27) Sajiki, H.; Yamada, A.; Yasunaga, K.; Tsunoda, T.; Amer, M. F. A.; Hirota, K. A Novel Chemical Modification at the 5-Position of Uridine Derivatives. Tetrahedron Lett. 2003, 44, 2179-2181.

(28) Yamagata, Y.; Fujii, S.; Fujiwara, T.; Tomita, K.-I.; Ueda, T. Synthesis and Molecular Conformation of 2',3'-O-Isopropylidene-5' Deoxy-6(R),5'-Cyclo-5,6-Dihydrouridine. BBA, Biochim. Biophys. Acta, Nucleic Acids Protein Synth. 1981, 654, 242-248.

(29) Yoshimura, Y.; Takahata, H. Recent Advances in Cyclonucleosides: C-Cyclonucleosides and Spore Photoproducts in Damaged DNA. Molecules 2012, 17, 11630-11654.

(30) Reist, E. J.; Benitez, A.; Goodman, L. The Synthesis of Some 5'Thiopentofuranosylpyrimidines1. J. Org. Chem. 1964, 29, 554-558.

(31) Crampton, K. T.; Rathur, A. I.; Nei, Y.-W.; Berden, G.; Oomens, J.; Rodgers, M. T. Protonation Preferentially Stabilizes Minor Tautomers of the Halouracils: IRMPD Action Spectroscopy and Theoretical Studies. J. Am. Soc. Mass Spectrom. 2012, 23, 14691478.

(32) Wu, R. R.; Yang, B.; Frieler, C. E.; Berden, G.; Oomens, J.; Rodgers, M. T. Diverse Mixtures of 2,4-Dihydroxy Tautomers and O4 Protonated Conformers of Uridine and $2^{\prime}$-Deoxyuridine Coexist in the Gas Phase. Phys. Chem. Chem. Phys. 2015, 17, 25978-25988.

(33) Anzai, K.; Uzawa, J. Cyclonucleoside Formation and Ring Cleavage in the Reaction of 2',3'-O-Isopropylideneadenosine with Benzoyl Chloride and Its Substituted Derivatives. J. Org. Chem. 1984, 49, 5076-5080.

(34) Pastuch-Gawołek, G.; Gillner, D.; Król, E.; Walczak, K.; Wandzik, I. Selected Nucleos(t)Ide-Based Prescribed Drugs and Their Multi-Target Activity. Eur. J. Pharmacol. 2019, 865, 172747.

(35) Veres, Z.; Szabolcs, A.; Szinai, I.; Dénes, G.; Kajtár-Peredy, M.; Ötvös, L. 5-Substituted-2,2'-Anhydrouridines, Potent Inhibitors of Uridine Phosphorylase. Biochem. Pharmacol. 1985, 34, 1737-1740. 